\title{
IMMIGRATION BILL 2007: SPECIAL ADVOCATES AND THE RIGHT TO BE HEARD
}

\author{
Lani Inverarity*
}

\begin{abstract}
The increasing role of "special advocates" in common law jurisdictions raises fundamental questions about the development of the law in response to new challenges and the extent to which individual rights can be abrogated in the name of national security. Special advocates are employed to examine and challenge classified evidence, withheld from affected persons and their legal advisors, in closed proceedings. They are, notionally, representing the affected person, but face an almost complete restriction on communication once exposed to the classified evidence. This is strikingly at odds with long-established norms of advocacy and a fair hearing, leading the United Kingdom Joint Committee on Human Rights to describe the system as "Kafkaesque". ${ }^{1}$ The special advocate function, widely utilised in the United Kingdom, will be statutorily introduced into New Zealand with the passing of the Immigration Bill 2007, mirroring a similar development in Canada. The Bill extends the use of classified information in immigration decision-making and allows for special advocates to examine and challenge classified evidence in review, appeal or detention proceedings. That Bill is the subject of this article.
\end{abstract}

\section{INTRODUCTION}

This article examines the introduction of the special advocate function to New Zealand and its premise that some representation is better than none at all. As background, this article briefly describes the developments leading to the Bill and the introduction of the special advocate function. It then questions whether special advocates can guarantee proceedings that are at least "fair enough" in light of the New Zealand Bill of Rights Act 1990 (Bill of Rights Act) protection of "the principles of natural justice". ${ }^{2}$

* Submitted as part of the LLB(Hons) programme at Victoria University of Wellington. I would like to acknowledge the assistance of Claudia Geiringer and Judge Ian Borrin.

1 Joint Committee on Human Rights "Counter-Terrorism Policy and Human Rights: 28 days, Intercept and Post-Charge Questioning" (16 July 2007) HL 157/HC 394, para 210.

2 New Zealand Bill of Rights Act 1990, s 27(1). 
The article concludes that, while the non-disclosure of classified information and the use of the special advocates does not satisfy the right to be heard, in certain circumstances and with certain improvements, it may nonetheless meet the requirements of natural justice or at least constitute a justified breach in light of national security concerns and the relative underdevelopment of due process protection in the immigration context. However, there is a real danger that the special advocate function established by the Bill, as drafted, merely gives a false impression of more fairness, given the significant extension of the use of classified information.

\section{BACKGROUND}

\section{A Immigration Act 1987}

The non-disclosure of classified information in immigration decision-making is a relatively recent development; prior to 1999 individuals being deported from New Zealand were entitled to know all the evidence against them. ${ }^{3}$ However, this requirement was seen to give insufficient protection to sensitive security information; the New Zealand Security Intelligence Service (SIS) claimed that relevant information was being withheld from immigration decision-making, due to concerns that disclosure might jeopardise intelligence-gathering operations and sources. ${ }^{4}$

In response, Part 4A was added to the Immigration Act 1987 (1987 Act) by the Immigration Amendment Act 1999. Under Part 4A, the Director of Security can certify, on the basis of classified security information, that an individual's continued presence in New Zealand constitutes a threat to national security. ${ }^{5}$ Affected persons are entitled to review of the security risk certificate by the Inspector-General of Intelligence and Security, ${ }^{6}$ but do not have access to any of the relevant classified information, ${ }^{7}$ restricting their ability to challenge the case against them. If the Minister of Immigration (Minister) elects to rely on the certificate, the affected person may be deported under section 72 of the 1987 Act.

Part 4A has been used once, controversially, in the case of Ahmed Zaoui.

\section{B Ahmed Zaoui}

An Algerian national, Mr Zaoui sought refugee status in New Zealand in December 2002, which was granted by the Refugee Status Appeals Authority in August 2003. However, in March 2003 the Director of Security issued a security risk certificate in respect of Mr Zaoui. Review by the

3 Immigration Act 1987, s 82(1)(c).

4 Immigration Amendment Bill 1998, no 16-1 (explanatory note) iii.

5 Immigration Act 1987, s 114D(1).

6 Ibid, s 114I.

7 Ibid, s 114H(2)(b). 
Inspector-General was initiated and his interlocutory decision became subject to extensive judicial review proceedings. ${ }^{8}$

The Zaoui litigation, and the subsequent public conversation, highlighted fundamental flaws in Part 4A of the 1987 Act; the lengthy, complex decision-making and review processes were unacceptable to both the Crown and the affected person, ${ }^{9}$ with inadequate human rights protections underlying legal argument throughout, including at the Supreme Court level.

Zaoui also saw New Zealand's first experience with special advocates. The Inspector-General, under statutory authority to regulate his procedure, ${ }^{10}$ appointed a security-cleared lawyer (Stuart Grieve QC, later assisted by a junior) to act on Zaoui's behalf in relation to the classified information on review. The special advocates were able to view SIS material not previously disclosed to Zaoui or his legal advisers and make challenges to that material in closed proceedings. ${ }^{11}$ Critically, however, they could not convey to Zaoui what was contained in the classified material, nor receive instructions based on it. ${ }^{12}$ Unfortunately, from an academic perspective, the role was not ultimately tested as the Director of Security withdrew the security risk certificate on 13 September 2007.

\section{Overseas Developments}

The special advocate brief employed by the Inspector-General in Zaoui was modelled on the function established in the United Kingdom following the decision of the European Court of Human Rights in Chahal v United Kingdom (Chahal). ${ }^{13}$

In Chahal, the European Court criticised the review of detention and deportation of foreign nationals on the basis of national security interests by an anonymous advisory panel with no power of decision, whose advice to the Home Secretary was not disclosed, with no entitlement to legal representation for an affected person and only an outline of the grounds for deportation disclosed. ${ }^{14}$

In response, the United Kingdom Parliament established the Special Immigration Appeal Commission (SIAC) to deal with immigration and asylum appeals involving national security

8 Zaoui v Attorney-General (No 2) [2004] 2 NZLR 339 (HC); [2005] 1 NZLR 690 (CA); [2006] 1 NZLR 289 (SC).

9 See Department of Labour Immigration Act Review: Part 4A Report Back (Wellington, 2007) 6-7.

10 Inspector-General of Intelligence and Security Act 1996, s 19 incorporated into Immigration Act 1987, s $114 \mathrm{I}(6)(\mathrm{b})$.

11 Hon Paul Neazor, Inspector-General of Intelligence and Security, to the author (1 July 2008) Letter.

12 Ibid.

13 Ibid.

14 Chahal v United Kingdom (1996) 23 EHRR 413, para 130 (ECHR) Judgment of the Court. 
issues. ${ }^{15}$ Where an appeal is likely to involve classified security information, the Attorney-General appoints a special advocate to represent the interests of the affected person. ${ }^{16}$ The special advocate's role is to challenge the classified nature of the evidence and its credibility; however it is significantly restricted in the latter by an almost total restriction on communication with the affected person and his or her legal advisors. ${ }^{17}$

This special advocate model has also been adopted in Canada following the Supreme Court decision in Charkaoui $v$ Minister of Citizenship and Immigration (Charkaoui). ${ }^{18}$ The Court concluded that the review by a Federal Court Judge of the "reasonableness" of a security risk certificate, conducted ex parte if disclosure would be injurious to national security or to the safety of any person, denied the right to a fair hearing by not providing an effective substitute for informed participation when less intrusive alternatives (such as the United Kingdom's special advocate model) were available. ${ }^{19}$ In February 2008, the Canadian Parliament passed legislation establishing the special advocate function. ${ }^{20}$

The influence of international developments in the adoption of the special advocate function in New Zealand is acknowledged by the explanatory note to the Bill: "These provisions [relating to the use of classified information] draw on current international standards and experience...". ${ }^{21}$

\section{IMMIGRATION BILL 2007}

Prior to the November 2008 election, the Transport and Industrial Relations Select Committee reported on the Bill and recommended that it be passed. ${ }^{22}$ The Bill was reinstated by the new government and has now passed its second reading.

A significant feature of the Bill is the ability of immigration decision-makers "to use classified information in a wider range of decision making with special safeguards." ${ }^{23}$ As the scope for the

15 Treasury Solicitors Department Special Advocates: A Guide to the Role of Special Advocates and the Special Advocates Support Office (SASO) Open Manual (London, 2006) para 6.

16 Special Immigration Appeals Commission Act 1997 (UK), s 6.

17 Treasury Solicitors Department, above n 15, para 108.

18 Charkaoui v Canada (Citizenship and Immigration) [2007] 1 SCR 350 [Charkaoui].

19 Ibid, para 87 McLachlin CJ for the Court.

20 An Act to amend the Immigration and Refugee Protection Act (certificate and special advocate) and to make a consequential amendment to another Act S C 2008 c C-3.

21 Immigration Bill 2007, no 132-1 (explanatory note) iii.

22 Ibid, no 132-2 (Select Committee report).

23 Ibid, no 132-1 (explanatory note) ii (emphasis added). 
use of classified information is the basis for the involvement of special advocates, this is the starting point for my analysis.

\section{A Classified Information}

The extension of the use of classified information is a dramatic departure from the security risk certificate regime under Part 4A of the 1987 Act.

Classified information is no longer limited to classified security information. Clause 5(1) of the Bill defines classified information as "information that the chief executive of a relevant agency certifies in writing cannot be disclosed". ${ }^{24}$ A "relevant agency" is any of 14 New Zealand government agencies, ${ }^{25}$ intended to encapsulate "security, defence, law enforcement, and border agencies, along with the Ministry of Foreign Affairs and Trade and the Department of Internal Affairs". ${ }^{26}$ And, as the relevant agency is the agency "that holds, was the source of, or was provided with" the information, the potential sources of the information are infinitely wider. ${ }^{27}$

The Immigration Act Review discussion paper, circulated to invite comment on the proposed legislation, envisaged "classified information" capturing information relating to "criminality, identity, or credibility generally". ${ }^{28}$ This is a significant extension from the 1987 Act, which was limited to classified security information: "information about the threat to security, public order, or public interest posed by an identifiable individual which is held by the New Zealand Security Intelligence Service". ${ }^{29}$

The effect of this wider definition is highlighted by the grounds on which information can be classified. Clause 5 retains the two step test from the 1987 Act, whereby the information must be of a certain kind and disclosure must be likely to have a certain effect. ${ }^{30}$ Clause 5 (2) provides that information may be classified if it might lead to the identification or provide details of the source, nature, content or scope of the information or assistance or operational methods available to or undertaken by the relevant agency, or has been provided by a foreign government, agency or international organisation on a confidential basis. ${ }^{31}$ Clause 5(3) provides that the disclosure of that

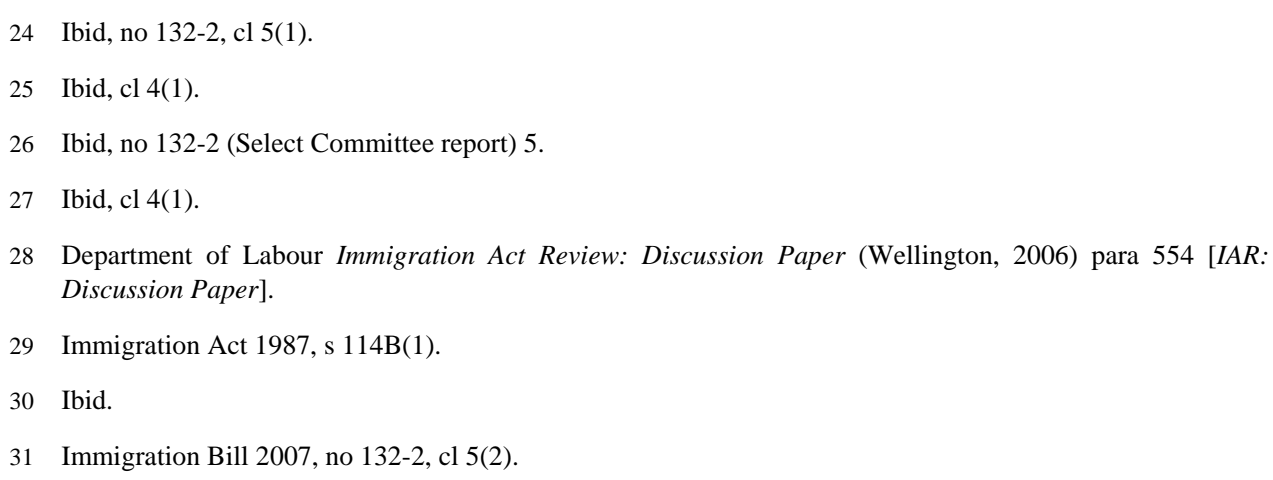


information must be likely to prejudice the security, defence or international relations of New Zealand, the entrusting of information to the Government of New Zealand or the maintenance of the law, or to endanger the safety of any person. ${ }^{32}$

These grounds have not been significantly widened from the 1987 Act, except to the extent that this results from the wider definition of classified information. For example, under subclause (2) "the source, nature, content, or scope of the information..." is considerably wider once it is taken out of the security and intelligence context and applied to the 14 relevant agencies under clause 4(1). Further, subclause (3), which includes disclosure likely to "prejudice the entrusting of information to the New Zealand Government"; when taken out of the security and intelligence context, where New Zealand's national security agencies rely on foreign intelligence, the argument for non-disclosure is not necessarily compelling.

Clause 30(1) then provides that "classified information may be relied on in making decisions or determining proceedings under this Act if the Minister determines that the classified information relates to matters of security or criminal conduct." 33

The Select Committee notably removed from this clause the ability to use classified information on the basis that it relates to "matters that may have a significant impact on New Zealand's international reputation". ${ }^{34}$ In doing so the Committee acknowledged concerns that such a justification would be subjective. ${ }^{35}$ Reputational risk, as a basis for derogating from individual rights, was described as "a makeweight" in the House of Lords decision of A v Secretary of State. ${ }^{36}$

However, the definition of security under clause 4(1) is so broad as to render this deletion almost futile. As well as covering defence, espionage, sabotage, organised crime and terrorism, the definition includes "activities in or relating to New Zealand that ... affect adversely New Zealand's international wellbeing, reputation, or economic wellbeing". ${ }^{37}$ Thus reputational harm is still capable of grounding the use of classified information, under the guise of "matters relating to security".

Further, as participation in organised crime and terrorist activity is also covered by the definition of security, the inclusion of criminal conduct in clause 30(1) would cover entirely domestic, even minor, offending, and could extend to mere allegations.

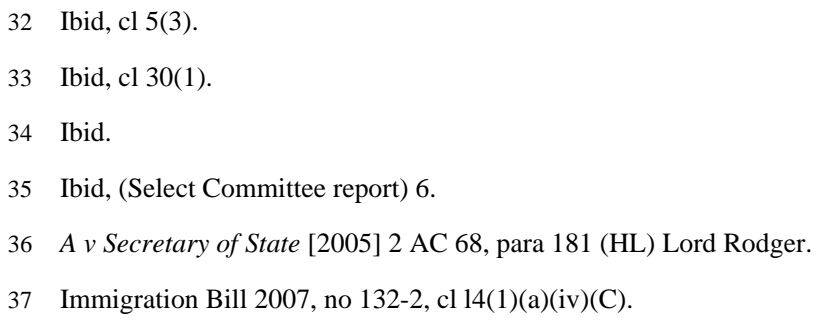


In summary, clause 30(1) provides a very wide basis for the use of classified information under the Bill.

Clause 30(2) then provides that the Minister may "rely on the information to make a decision under Part 3, 4, or 6"38 relating to visas, entry permission and deportation respectively. The Minister may also direct that the information be provided to the Immigration and Protection Tribunal (Tribunal) or court if it is to be relied upon in any proceedings. ${ }^{39}$ In comparison, the 1987 Act only provides for the use of classified security information (without full disclosure) under Part 4A, that is, where a security risk certificate has been issued by the Director of Security.

The wider use of classified information is proposed to cover "people who present a risk to New Zealand's interests, but whose risk can be managed by preventing further extensions of their stay." 40 In such cases an adverse decision may result in the affected person being in New Zealand unlawfully, ${ }^{41}$ and consequently liable for deportation under clause 143(1).

While it is undoubtedly important "that immigration decisions are not made in error, or without full consideration of the facts", ${ }^{42}$ the issue remains that the classified evidence is not disclosed to, or able to be challenged by, an affected person, with potentially very serious consequences.

\section{B Safeguards}

In an attempt to balance the extended definition and use of classified information, the Bill provides for limited disclosure, appeal and review rights, and the use of special advocates.

\section{Summary and reasons}

Clauses 34 and 35 of the Bill provide for limited disclosure in relation to certain decisions involving classified information, including residence class visa applications, onshore temporary or limited visa applications, liability for deportation and decisions relating to refugee or protection status. ${ }^{43}$

Clause 34(2) requires that, before a relevant decision is made in reliance on potentially prejudicial classified information, a summary of allegations arising from the classified information is to be forwarded to the affected person for comment. ${ }^{44}$ If proceedings involving classified

\footnotetext{
38 Ibid, cl 30(2)(a).

39 Ibid, cl 30(2) subparas (b) and (c).

40 IAR: Discussion Paper, above n 28, para 564.

41 Immigration Bill 2007, no 132-2, cl 5B(1).

42 IAR: Discussion Paper, above n 28, para 573.

43 Immigration Bill 2007, no 132-2, cl 34(1).

44 Ibid, cl 34(2).
} 
information go before the Tribunal, the summary must be approved by the Tribunal. ${ }^{45}$ The Select Committee notably amended the Bill to the effect that classified information cannot be relied on in making the relevant decision to the extent that the allegations arising from it cannot be summarised. ${ }^{46}$

Once a decision has been made in reliance on classified information, and the decision is prejudicial to the affected person, clause 35 provides that he or she must be informed, inter alia, that classified information was relied on and of the reasons for the decision (except to the extent that this would involve prejudicial disclosure in terms of clause 5(3)). ${ }^{47}$

Experience in Canada and the United Kingdom has shown such summaries to be extremely general, with "protective anxiety" on behalf of information sources. ${ }^{48}$ One anticipates then, that a summary of allegations and reasons, if available at all, will likely contain insufficient information to genuinely challenge the government's case.

\section{Appeal and review rights}

Part 7 of the Bill establishes the Tribunal as "a specialist Tribunal to determine appeals and other matters" under the Bill, replacing the four existing appeal bodies and the Inspector-General's review of the use of classified information. ${ }^{49}$

Appeals to the Tribunal are principally limited to residence, protection and deportation determinations, ${ }^{50}$ with the notable exception of non-citizens liable for deportation by Order in Council as a threat to national security under clause $152 .{ }^{51}$ These "appeals" are not appeals in their usual sense; rather, they are de novo determinations of liability (appeals on the facts) or first instance considerations of humanitarian grounds that would make it unjust or unduly harsh to deport

45 Ibid, cl 216(2).

46 Ibid, cls 34(2A) and 216(2A).

47 Ibid, cl 35.

48 Craig Forcese and Lorne Waldman Seeking Justice in an Unfair Process: Lessons from Canada, the United Kingdom, and New Zealand on the Use of "Special Advocates" in National Security Proceedings (Ottawa, 2007) 12; Joint Committee on Human Rights "Review of Counterterrorism Powers" (21 July 2004) HL 158/HC 713, para 22.

49 Immigration Bill 2007, no 132-2, cl 169(b).

50 Ibid, cls 180(1) and 185(1).

51 Ibid, cl 185(2)(c). 
an affected person (appeals on humanitarian grounds). ${ }^{52}$ Further appeals, on points of law only, from decisions of the Tribunal are available by leave to the High Court and Court of Appeal. ${ }^{53}$

Where an "appeal" to the Tribunal is not available, judicial review in the High Court is the only means of independent review. This is despite the Select Committee's concern (in relation to residence class visa determinations) that "excluding such appeals where classified information was relied on would prevent appropriate independent scrutiny by the Tribunal of the veracity and relevance of the classified information in question." 54

Where proceedings before the Tribunal involve classified information, the Tribunal is to consist of up to three District Court Judges, ${ }^{55}$ and is to have access to the classified information relied on in the decision or first raised in the appeal or matter. ${ }^{56}$ Prior to substantively determining the appeal or matter, the Tribunal is to establish whether the classified information is relevant, whether it should be classified and whether it is credible. ${ }^{57}$

Following Select Committee amendment, clause 194 of the Bill provides for the Tribunal's proceedings to be inquisitorial, adversarial or a mixture of the two, in any particular case. ${ }^{58}$ Thus while the Tribunal has powers of investigation, ${ }^{59}$ there is also provision in the Bill for a more adversarial hearing, particularly in relation to appeals against liability for deportation or proceedings involving refugee or protection status.

\section{Special Advocates}

A special advocate under the Bill is a special security-cleared lawyer recognised as such by an agency designated for the purpose by the Prime Minister (designated agency). ${ }^{60}$ It is unclear at this stage whether a new agency will be established, or an existing agency extended, to accommodate this function.

\footnotetext{
52 Ibid, cls 181 and 186.

53 Ibid, cl 219.

54 Ibid, (Select Committee report) 21.

55 Ibid, cl 214.

56 Ibid, cls 215 and 231(1).

57 Ibid, cl 217.

58 Ibid, cl 194(2).

$59 \quad$ Ibid, $2^{\text {nd }}$ sch, cls 11 and 12.

60 Ibid, cl 236.
} 
The role of the special advocate is to represent an affected person in proceedings involving classified information. ${ }^{61}$ To this end, the special advocate may lodge or commence proceedings on behalf of the affected person and participate in proceedings from which that person is excluded. ${ }^{62}$ The special advocate must be provided with access to the classified information relied on in making the decision or provided to the Tribunal (or court). ${ }^{63}$

The appointment of a special advocate is made by the designated agency from a list of three possible advocates provided to an affected person, on the choice of that affected person. ${ }^{64}$ If an affected person does not wish to appoint a special advocate, one will be appointed on his or her behalf. ${ }^{65}$ The actual and reasonable costs of the special advocate are to be met by the Department administering the Act. ${ }^{66}$

Prior to gaining access to the classified information, the special advocate can communicate with the affected persons and their private counsel "on an unlimited basis". ${ }^{67}$ However, once access has been provided, the special advocate must not communicate with affected persons or their counsel, except in writing through the Tribunal. ${ }^{68}$ The Tribunal will either forward the communication to the affected person or decline to do so on the basis that the communication would likely involve prejudicial disclosure. ${ }^{69}$ In making this determination the Tribunal may consult with the chief executive of the relevant agency and/or amend the communication as necessary. ${ }^{70}$

The only persons with whom the special advocate is able to communicate, once exposed to the classified information, and about any matter connected with the proceedings, are the Tribunal or court, the Minister or chief executive of the relevant agency, and persons with whom it is necessary to communicate for administrative purposes not connected with the substance of the proceeding. ${ }^{71}$

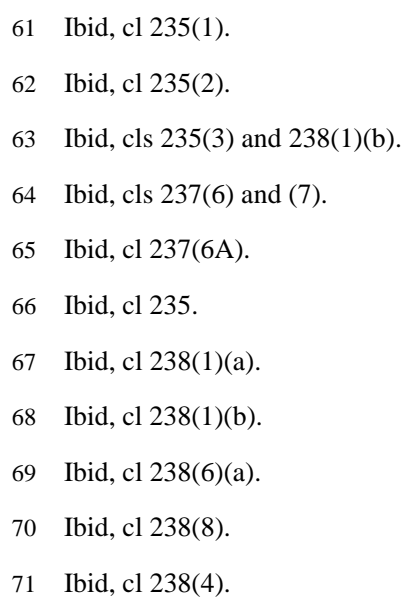


The effectiveness of a special advocate, purporting to represent an affected person, but unable to get comment from him or her on anything contained in the classified information, has been the subject of immense criticism in both the United Kingdom and Canada. ${ }^{72}$

While the special advocate can have unlimited contact with the affected person prior to disclosure of the classified information, the utility of this provision has been questioned. ${ }^{73}$ At that stage all are acting effectively in ignorance of the core government case, as the unclassified evidence may have little or no relation to the classified evidence and little assistance may be gained from the summary of evidence. Special advocates in the United Kingdom have also expressed concern that, as the SIAC (or Tribunal, in New Zealand's case) may consult with the relevant agency in determining whether or not a special advocate's communication with the affected person is appropriate, the agency will be alerted to a line of investigation. This places the affected person at a tactical disadvantage, and any decision not to pursue that line at the hearing may be viewed adversely.

The restriction on communication also precludes information sharing between special advocates, diminishing their capacity to identify inconsistent use of classified material between cases. ${ }^{74}$ Arguably, effective special advocate work in a common law system depends on access to precedent in closed matters. ${ }^{75}$

Following their study of special advocates in the United Kingdom, Canada and New Zealand (in Zaoui), Forcese and Waldham conclude that the possibility of a full answer and defence is basically non-existent without the ability to offer an exculpatory explanation of the sort that can only be derived from the affected person. ${ }^{76}$ Lord Bingham, dissenting in Roberts $v$ Parole Board (Roberts), also describes the special advocate as inevitably "taking blind shots at a hidden target."77

This position obviously raises significant concerns about the right to a fair hearing.

72 See Forcese and Waldham, above n 48; Joint Committee on Human Rights, above n 48; House of Commons Constitutional Affairs Committee "The Operation of the Special Immigration Appeals Commission (SIAC) and the use of Special Advocates" (3 April 2005) HC 323-1.

73 Forcese and Waldham, above n 48, 34.

74 Ibid, 29

75 Ibid

76 Ibid, 39.

77 Roberts v Parole Board [2005] 2 AC 738, para 18 (HL) Lord Bingham dissenting. 


\section{ANALYSIS}

\section{A Human Rights Framework}

\section{Fair hearing rights}

Non-disclosure of evidence challenges a basic premise of the right to a fair hearing: the right to be heard. In Kanda $v$ Government of the Federation of Malaya, the Privy Council held that: ${ }^{78}$

If the right to be heard is to be a real right which is worth anything, it must carry with it a right in the accused man to know the case which is made against him. He must know what evidence has been given and what statements have been made affecting him: and then he must be given a fair opportunity to correct or contradict them... It follows, of course, that the judge or whoever has to adjudicate must not hear evidence or receive representations from one side behind the back of the other.

The strongest protections for the right to be heard are contained in section 25 of the Bill of Rights Act, which reads, in part: ${ }^{79}$

Everyone who is charged with an offence has ... the following minimum rights:

(a) The right to a fair and public hearing by an independent and impartial court: ...

(e) The right to be present at the trial and to present a defence: ...

(f) The right to examine the witnesses for the prosecution and to obtain the attendance and examination of witnesses for the defence under the same conditions as the prosecution.

However, advice to the Attorney General on the Bill states: "we do not consider that sections 24 and 25 of [the Bill of Rights Act] are engaged on the basis that they deal with criminal procedure and those who have been charged with an offence." 80

This has also been the prominent view of the courts. The Court of Appeal in Zaoui v AttorneyGeneral (No 1), regarding bail, held that section 24 was only available to those charged with a criminal offence and could not be relied upon by Zaoui, who was in immigration detention. ${ }^{81}$

In Canada, early challenges to the security certificate review procedure failed on a similar basis. In Ahani v Canada, the Federal Court held that the plaintiff's argument that the lack of disclosure

78 Kanda v Government of the Federation of Malaya [1962] AC 322, 337 (PC) Lord Denning for the Court.

79 New Zealand Bill of Rights Act 1990, s 25.

80 J Orr and M Dugdale "Consistency with the New Zealand Bill Of Rights Act 1990: Immigration Bill" (advice to the Attorney-General) (20 July 2007) para 147.

81 Zaoui v Attorney-General [2005] 1 NZLR 577, para 267 (CA) O'Regan J. The practical significance of this ruling was diminished by the Supreme Court's decision that there is a common law right to bail that can be invoked by all detained persons regardless of the reason for their detention. 
and opportunity to challenge the information against him was a violation of the principles of fundamental justice was based on criminal law principles that had no application in his immigration case. ${ }^{82}$

This position is problematic as immigration measures are often used to detain or deport those suspected of involvement in criminal activities, allowing them to be dealt with on an administrative basis without the procedural protections they would be afforded if actually charged. ${ }^{83}$ Further, an adverse immigration determination could potentially result in graver consequences than those permitted at criminal law, including prolonged detention or deportation to persecution or worse.

These concerns can claim some support from the Supreme Court of Canada's decision in Charkaoui, where the Court held that, in determining whether protections contained in the Canadian Charter apply, courts "must look at the interests at stake rather than the legal label attached to the impugned legislation." 84

Similarly, in Engel $v$ Netherlands, the European Court of Human Rights held that, in determining whether the specific rights for those charged with a criminal offence in Article 6 of the European Convention on Human Rights (ECHR) applied, courts had jurisdiction to look beyond the classification given to an offence to "satisfy itself that the disciplinary does not improperly encroach upon the criminal". ${ }^{85}$

The above arguments were considered by the House of Lords in Secretary of State for the Home Department $v M B$ and $A F(M B)$, concerning the application of Article 6 to "control order" proceedings (which also involved the use of special advocates where classified information was relied upon). ${ }^{86}$ Here, the affected persons, reasonably suspected of involvement in terrorist-related activity, were subject to restrictions on their place of residence, movement, activities, communications, and associations, and were required to allow searches of themselves and theirs residence, and to wear electronic monitoring equipment, at all times. ${ }^{87}$

82 Ahani v Canada [1995] 3 FC 669, 694 and 696 (FCC) McGillis J.

83 John Ip "Comparative Perspectives on the Detention of Terrorist Suspects" (2007) 16 Transnat'l L \& Contemp Probs 773, 810 and 823-4; Parliamentary Information and Research Service "Bill C-3: An Act to Amend the Immigration and Refugee Protection Act (Certificate and Special Advocate) and to make a consequential amendment to another Act" (2 November 2007) LS-567E, 2 fn 3.

84 Charkaoui, above n 18, para 18 McLachlin CJ for the Court.

85 Engel $v$ Netherlands (8 June 1976) ECHR 5100/71, para 81 Judgment of the Court.

86 Secretary of State for the Home Department $v$ MB and AF [2008] 1 AC 440 (HL) [MB].

87 Ibid, para 7 Lord Bingham. 
Although their Lordships held that such proceedings did not qualify as "criminal", as there was only an assertion of suspicion of criminal conduct, and the control order was preventative, rather than punitive or retributive, in purpose, ${ }^{88}$ Lord Bingham observed that: ${ }^{89}$

...judges have regarded the classification of proceedings as criminal or civil as less important than the question of what protections are required for a fair trial... and have held that the gravity and complexity of the charges and of the defence will impact on what fairness requires.

A similar approach has been taken in New Zealand. The relationship between sections 24, 25 and 27 was briefly discussed by the Court of Appeal in Drew v Attorney General (Drew), ${ }^{90}$ concerning the right of a serving prisoner to be represented by a lawyer at an appeal hearing for a disciplinary offence before a Visiting Justice. While it was ultimately left open whether sections 24 and 25 applied, the Court of Appeal recognised that there were arguments for such an application. ${ }^{91}$ The Court did not have to decide this point as the lack of legal representation in Mr Drew's case constituted a breach of the common law principles of natural justice, as affirmed by section 27(1) of the Bill of Rights Act. ${ }^{92}$

At the very least then courts can look to the guarantees contained in section 25 of the Bill of Rights Act to inform the minimum standards applicable in any particular case under section 27(1) and the common law principles of natural justice.

\section{Natural justice}

The common law concept of natural justice requires administrative bodies to act fairly when reaching a decision that could adversely affect those who are the subject of the decision. ${ }^{93}$ The Privy Council in Furnell $v$ Whangarei High Schools Board described natural justice as "fairness writ large and juridically" and "fair play in action". 94

The content of the rules and the standards imposed by natural justice are infinitely flexible, and "must depend upon the circumstances of the case, the nature of the inquiry, the rules under which the tribunal is acting, the subject-matter that is being dealt with, and so forth." 95 "The overriding

88 Ibid, para 24 Lord Bingham.

89 Ibid, para 17 Lord Bingham.

90 Drew v Attorney-General [2002] 1 NZLR 58 (CA) [Drew].

91 Ibid, para 76 Richardson P, Keith, Blanchard and Tipping JJ.

92 Ibid, para 79 Richardson P, Keith, Blanchard and Tipping JJ.

93 William Wade and Christopher Forsyth (eds) Administrative Law (9 ed, Oxford University Press, Oxford, 2004) 494.

94 Furnell $v$ Whangarei High Schools Board [1973] 2 NZLR 705, 718 (PC) Lord Morris.

95 Russell v Duke of Norfolk [1949] 1 All ER 109, 118 (CA) Tucker LJ. 
requirement is that the guiding principles should be respected and observed... the touchstone is to ascertain what justice requires in the circumstances of the particular case." 96

One such guiding principle is the right to notice and the opportunity to be heard in respect of matters which might be considered in the course of a decision affecting a person's rights or interests. ${ }^{97}$

At common law, the requirements of natural justice are determined by statutory interpretation and supplementation. Where an empowering statute omits express protection of procedural fairness, "the justice of the common law will supply the omission of the legislature". ${ }^{98}$ And where Parliament does confer statutory protections, but these are insufficient, courts may supplement that procedure by reference to natural justice, provided that this does not frustrate the apparent purpose of the legislation. ${ }^{99}$ As common law natural justice rests upon statutory implication, its application "must always be in conformity with the scheme of the Act." 100

The right to observance of the principles of natural justice is affirmed by section 27(1) of the Bill of Rights Act:

Every person has the right to the observance of the principles of natural justice by any tribunal or other public authority which has the power to make a determination in respect of that person's rights, obligations or interests protected or recognised by law.

In Combined Beneficiaries Union v Auckland City COGS Committee ( $C B U)$, the Court of Appeal confirmed that: ${ }^{101}$

the content of the s 27(1) right to natural justice was intended to be and is (at least) coincident with that at common law (although, as at common law, that would not limit later development of the right). This is supported by the plain words of the provision, the legislative history and the policy of the Bill of Rights.

However, the Bill of Rights Act also adds a normative, evaluative character, allowing courts to consider the extent to which natural justice ought to apply, notwithstanding the particular statutory procedure. ${ }^{102}$ The Court of Appeal in $C B U$ affirmed the statement in the Bill of Rights White Paper

$96 \quad R v H[2004] 2$ AC 134, para 33 (HL) Lord Bingham for the Court.

97 Zaoui v Attorney-General (No 2), above n 8, para 4 (CA) Anderson P.

98 Cooper v Wandsworth Board of Works (1863) 14 CB (NS) 180, 194; 143 ER 414, 420 (CCP) Byles J.

99 Wiseman v Borneman [1971] AC 297, 308 (HL) Lord Reid.

100 Wade, above n 93, 497.

101 Combined Beneficiaries Union Incorporated v Auckland City COGS Committee [2008] NZCA 423, para 50 Glazebrook and Hammond JJ [CBU].

102 Ibid, para 24 Glazebrook and Hammond JJ. 
that "s[ection] 27(1) will not change the courts' normal and long-standing task, except to the extent that the principles [of natural justice] will now have an enhanced status."103

In summary, section 27(1) will provide the framework for my analysis, but case law as to the determination of "the principles of natural justice" at common law will necessarily be utilised, to the extent that this is consistent with the normative affirmation of those principles in the Bill of Rights Act.

\section{Section 5 Bill of Rights Act}

In the context of natural justice it is unclear whether the additional balancing of section 5 of the Bill of Rights Act is required. Section 5 provides for "such reasonable limits prescribed by law as can be demonstrably justified in a free and democratic society."104

The Court of Appeal in Drew observed that "as natural justice is itself a flexible concept which adapts to particular situations, where its principles apply there is no room and no need for the operation of section 5." 105 This is supported by the conceptual view that, as natural justice is about minimum standards, it would be counterintuitive to further limit those standards. ${ }^{106}$

However, there is little consensus, or authority, on this point. The counterview is that human rights require a generous interpretation, with limits carefully and transparently analysed under section 5, in accordance with the framework set out by the Bill of Rights Act. ${ }^{107}$ This position has support from the Supreme Court of Canada, which held in Charkaoui that, unlike section 1 of the Canadian Charter (the equivalent of section 5), section 7 is not concerned with whether a limit on life, liberty or security is justified, but with whether the limit has been imposed in a way that respects the principles of fundamental justice. ${ }^{108}$

In the interests of clarity, and the absence of settled authority to the contrary, this article analyses the Bill in terms of both section 27(1) and section 5.

103 Ibid.

104 New Zealand Bill of Rights Act 1990, s 5.

105 Drew, above n 90, para 67 Richardson P, Keith, Blanchard and Tipping JJ.

106 Paul Rishworth and others The New Zealand Bill of Rights (Oxford University Press, Melbourne, 2003) 173 and 761.

107 Andrew Butler and Petra Butler The New Zealand Bill of Rights Act: A Commentary (Lexis Nexis NZ, Wellington, 2005) 25.5.2.

108 Charkaoui, above n 18, para 21 McLachlin CJ for the Court. 


\section{B The Right to be Heard}

1 Is section 27(1) engaged?

For section 27(1) to be engaged, an affected person must be subject to "a determination", "by any tribunal or other public authority", "in respect of that person's rights, obligations or interests protected or recognised by law". ${ }^{109}$

As previously discussed, classified evidence may be used by the Minister, Tribunal or courts, in determinations regarding visas, entry permission, deportation, warrants of commitment and protection status, where the classified information relates to matters of security or criminal conduct. ${ }^{110}$

The Court of Appeal in $C B U$ accepted that "the expression [in section 27(1)] "any tribunal or other public authority" can be read as a shorthand reference back to those identified in s 3 of the Bill of Rights which sets out the actors to whom the Bill of Rights applies." ${ }^{111}$ Section 3 provides that:

This Bill of Rights applies only to acts done-

(a) By the legislative, executive, or judicial branches of the government of New Zealand; or ...

The Minister, the Tribunal and courts clearly fall within section 3(a), as members of the executive and judicial branches of the government of New Zealand.

The Court of Appeal in $C B U$ also held that: ${ }^{112}$

S[ection] 27(1) cannot, without robbing it of much of its force, be read as dealing only with actual rights, obligations or interests. It must also extend at least as far as claimed rights, obligations and interests. There is no reason in principle why it should not also extend to discretionary determinations. A discretion, if exercised in favour of the applicant, can result in a right.

In support of this contention, the Court noted the decision of the Supreme Court in Udompun $v$ Minister of Immigration and New Zealand Police, ${ }^{113}$ refusing leave to appeal against a decision concerning alleged breaches of section 27(1) of the Bill of Rights Act in the course of refusing entry to New Zealand. ${ }^{114}$ The Supreme Court found that each of the proposed grounds of appeal entailed

109 New Zealand Bill of Rights Act 1990, s 27(1).

110 Immigration Bill 2007, no 132-2, cl 30.

$111 C B U$, above n 101, para 13 Glazebrook and Hammond JJ.

112 Ibid, para 17 Glazebrook and Hammond JJ.

113 Udompun v Minister of Immigration and New Zealand Police [2006] 1 NZLR 343 (SC).

$114 C B U$, above n 101, para 40 Glazebrook and Hammond JJ. 
an application of uncontentious principle to the facts: apparently accepting that section 27(1) applies to entry decisions at the border, even though there is no "right" of entry. ${ }^{115}$

In Dayaganasi v Minister of Immigration, Cooke J (as he then was) similarly held that, concerning the application of natural justice to a limited appeal from automatic deportation liability: ${ }^{116}$

The present is not a case of an entrenched right, but if the Minister decides the specific and quite narrowly-worded question in the appellant's favour and consequently orders that the appellant be not deported, the Act requires him to issue a permit. So it seems to me by no means a distortion of language to say that the Minister is determining a question affecting the rights of an individual.

This reasoning would equally apply to determinations of deportation liability, residence and protection status, being the determinations affecting the right of an individual to remain in New Zealand, and on what terms.

The engagement of section 27(1) entitles affected persons "to the observance of the principles of natural justice", the requirements of which depend in particular on the interests at stake and the nature of the proceedings.

\section{Requirements}

Lord Woolf in Roberts $v$ Parole Board held that "the [affected person] should have the benefit of a procedure which fairly reflects, on the facts of his particular case, the importance of what is at stake for him, as for society." 117

In cases involving immigration status, Elias J (as she then was) held in Ali v Deportation Review Tribunal that "high standards of fairness are required by natural justice because of the profound implications for the lives of those affected." 118

The Supreme Court of Canada in Charkaoui also emphasised that: ${ }^{119}$

It is one thing to deprive a person of full information where fingerprinting is at stake, and quite another to deny him or her of information where the consequences are removal from the country or indefinite detention.

115 Ibid; Udompun v Minister of Immigration and New Zealand Police, above n 113, para 7 Judgment of the Court.

116 Dayaganasi v Minister of Immigration [1980] 2 NZLR 130, 144 (CA) Cooke J.

117 Roberts $v$ Parole Board, above n 77, para 46 Lord Woolf.

118 Ali v Deportation Review Tribunal [1997] NZAR 208, 220 (HC) Elias J.

119 Charkaoui, above n 18, para 60 McLachlin CJ for the Court. 
The Supreme Court was particularly concerned with the possibility of grave consequences resulting from deportation, highlighted in the case of refugees and protected persons. ${ }^{120}$ Unsurprisingly, additional protections from deportation liability are provided for refugees and protected persons under the Bill.

A refugee is a person who "owing to a well founded fear of being persecuted ... is outside the country of his nationality and is unable or, owing to such fear, is unwilling to avail himself of the protection of that country." ${ }^{121}$ A refugee or refugee status claimant may be deported only if Article 32.1 or 33 of the Refugee Convention allows the deportation of the person, ${ }^{122}$ that is, on the grounds of national security or public order or as a danger to national security or the community.

A protected person is a person of whom there are substantial grounds for believing that he or she would be in danger of being subjected to torture, arbitrary deprivation of life or cruel treatment if deported from New Zealand. ${ }^{123}$ A protected person may only be deported to a place other than a place in respect of which the above risk applies. ${ }^{124}$

Thus establishing and maintaining refugee or protected person status is of principal importance in protecting serious life and liberty interests.

Other determinations also have potentially serious consequences: including warrant of commitment, deportation, and residence proceedings. The serious nature of the interests at stake is reflected in the Bill's provision for first instance or de novo determinations by the Tribunal of protection, residence and deportation proceedings (with the exception of clause 152 liability), and warrant of commitment proceedings in the District Court.

The essentially adversarial nature of these proceedings requires stronger protection of natural justice. Upjohn LJ in Re K (Infants) held that: ${ }^{125}$

It seems to be fundamental to any judicial inquiry that a person or other properly interested party must have the right to see all the information put before the judge, to comment on it, to challenge it and if needs be to combat it, and to try to establish by contrary evidence that it is wrong. It cannot be withheld

from him in whole or in part.

120 Ibid, paras 25 and 26 McLachlin CJ for the Court.

121 Convention Relating to the Status of Refugees (28 July 1951) 198 UNTS 137, art 1A(2).

122 Immigration Bill 2007, no 132-2, cl 153(3).

123 Ibid, cls 120 and 121.

124 Ibid, cl 153(4).

125 Re K (Infants) [1963] Ch 381, 405 (CA) Upjohn LJ. 
It was also material to the Court of Appeal decision in Drew that the role of the Visiting Justice: ${ }^{126}$

is predominantly that of an adjudicator required to make a decision on the evidence presented by the prison authorities and the inmate. The process has the usual hallmarks of an adversarial contest to which the principles of natural justice apply - the laying of a charge to be proved beyond reasonable doubt, the calling of evidence by the parties at a hearing and the right to cross-examine. The adjudicator is not empowered to conduct his or her investigations outside the hearing.

In respect of assistance given by the Justice to inmates, the Court of Appeal concluded that "at most, there is a slight inquisitorial element, but the task remains fundamentally one of adjudication between the cases which the parties have chosen to present." ${ }^{127}$

Proceedings involving classified information will generally rest upon an allegation of participation in criminal, terrorist, or other subversive activity, rendering the affected person's presence in New Zealand contrary to the public interest. This will require the production and examination of evidence, and legal argument regarding this, akin to criminal or serious disciplinary proceedings.

This is most significant in respect of a clause 152 determination that an affected person is a threat to national security: a serious allegation with potentially very serious consequences, allowing the deportation of a refugee despite an acknowledged risk of persecution. While this particular determination is not afforded an "appeal" to the Tribunal, the seriousness of this allegation and its consequences must require a meaningful opportunity to be heard before the Minister, in the first instance, and the court in judicial review proceedings.

The Tribunal will have the opportunity to review, de novo, evidence presented in respect of deportation and residence proceedings, and to make first instance determinations of protection status and humanitarian grounds rendering deportation unjust or unduly harsh to an affected person. The District Court will determine, at first instance, liability for detention under a warrant of commitment. Again, in each case, the production and examination of evidence, and legal argument concerning this, will be crucial and potentially complex.

In respect of the Tribunal, while the Bill provides for certain powers of investigation, ${ }^{128}$ there is no duty on the Minister or relevant agency to provide to the Tribunal any classified information other than that which "was relied on" in making the decision or first raised in the appeal or matter

126 Drew, above n 90, para 53 Richardson P, Keith, Blanchard and Tipping JJ.

127 Ibid, para 54 Richardson P, Keith, Blanchard and Tipping JJ.

128 Immigration Bill 2007, no 132-2, $2^{\text {nd }}$ sch, cl 11. 
before the Tribunal. ${ }^{129}$ Further, the use of special advocates and the provision for oral hearings demonstrates a commitment to a more adversarial proceeding where serious interests are at stake. ${ }^{130}$

The ordinary courts, on review, on appeal, and in respect of warrant of commitment proceedings, are similarly only provided with the classified information which "was relied on", in an even plainer adversarial context.

At the same time, a special advocate, while representing the interests of an affected person, is unable to take instructions from that person in relation to the classified information and has no express power under the Bill to request other government records believed to be relevant. Disclosure is highly unlikely to be complete; even acting in utmost good faith, the "protective anxiety" of intelligence agencies produces a different view as to what is relevant from that of a legal advocate. ${ }^{131}$ Further, special advocates in the United Kingdom report that often they only receive analytical summaries or assessments prepared by the security services, which quote from intercepted materials or other summaries, rather than actual transcriptions of intercepted communications. ${ }^{132}$ This increases the risk that the information is selective and at the very least deprives the special advocate of the full context of recorded conversations. Thus while the proceedings are adversarial, the protection afforded by this process is severely constrained.

In Charkaoui, it was material to the Supreme Court's decision that the reviewing judges of the Federal Court: ${ }^{133}$

do not possess the full and independent powers to gather evidence that exist in an inquisitorial process.

At the same time, the named person is not given the disclosure and the right to participate in the proceedings that characterize the adversarial process. The result is a concern that the judge, despite his or her best efforts to get all the relevant evidence, may be obliged - perhaps unknowingly - to make the required decision based on only part of the relevant evidence.

The risk is also present here that the Tribunal or court will not have all the information before them. There is a heavy burden on the special advocate to present the affected person's case, with insufficient ability to actually do so.

129 Ibid, cl 231(1).

130 Ibid, cl 208

131 Forcese and Waldham, above n 48, 62. See also MB, above n 86, para 66 Baroness Hale, where she states that: "There is ample evidence from elsewhere of a tendency to over-claim the need for secrecy in terrorism cases".

132 Forcese and Waldham, above $\mathrm{n} 48,40$.

133 Charkaoui, above n 18, para 50 McLachlin CJ for the Court. 
It is nonetheless accepted, however, that a balancing of competing public interests may nonetheless require the withholding of information from one of the parties.

In $\operatorname{Re} K$, the House of Lords held that the disclosure of confidential reports was a matter of discretion for the judge. ${ }^{134}$ The decisive factor was that the High Court was exercising wardship jurisdiction: its paramount consideration was the welfare of the child. ${ }^{135}$ Lord Devlin drew a distinction between ordinary adversarial proceedings in which natural justice must prevail and exceptional cases where other interests may have to be protected: ${ }^{136}$

Where the judge sits purely as an arbiter and relies on the parties for his information, the parties have a correlative right that he should act only on information which they have had the opportunity of testing. Where the judge is not sitting purely, or even primarily, as an arbiter but is charged with the paramount duty of protecting the interests of one outside the conflict, a rule that is designed for just arbitrament cannot in all circumstances prevail.

Similarly in Roberts, Lord Woolf held it was "particularly important" that "in the final balance, the [parole] board is bound to give preponderant weight to the need to protect innocent members of the public against any significant risk of serious injury". ${ }^{137}$ Lord Woolf concluded that measures necessary to protect the public interest were not necessarily inconsistent with achieving the "core, irreducible, minimum entitlement" of natural justice. ${ }^{138}$

And in $R v H$, the use of special advocates in criminal discovery proceedings concerning the doctrine of public interest immunity, enabled the court to reconcile "an individual defendant's right to a fair trial with such secrecy as is necessary in a democratic society in the interests of national security or the prevention or investigation of crime". ${ }^{139}$

There is a strong case that the Tribunal or court, in respect of proceedings involving classified information, are under a paramount duty to prevent the prejudicial disclosure of sensitive information, whilst enabling the removal from New Zealand of potentially dangerous individuals.

While these national security concerns mean that the right to be heard can not be absolute, none of the authorities mentioned above apply a consistent rule of non-disclosure. In $R e K$, the disclosure, or not, of confidential reports was a matter of discretion for the Judge. ${ }^{140}$ In Roberts, Lord Woolf

$134 \operatorname{Re}$ K (Infants) [1965] AC 201 (HL).

135 Ibid, 240 Lord Devlin.

136 Ibid, 240-241 Lord Devlin.

137 Roberts v Parole Board, above n 77, para 46 Lord Woolf.

138 Ibid, para 68 Lord Woolf.

$139 R v H$, above n 96, para 23 Lord Bingham for the Court.

$140 \operatorname{Re} K$ (Infants), above n 134, 241 Lord Devlin. 
held that the minimum entitlement of natural justice cannot be determined in the abstract; there must be a balancing exercise on the facts of the particular case. ${ }^{141}$ And in $R v H$, non-disclosure and the appointment of a special advocate in criminal discovery proceedings, "will always be exceptional, never automatic; a course of last and never first resort." 142

Even where non-disclosure is warranted, the ability of a special advocate to counterbalance the disadvantage to an affected person, will vary greatly between cases.

As a result, a majority of the House of Lords in $M B$ emphasised that the compliance of control order proceedings, involving the use of special advocates, with the right to a fair hearing had to be determined on a case by case basis. ${ }^{143}$ Baroness Hale explained that: ${ }^{144}$

[Compliance] would all depend upon the nature of the case; what steps had been taken to explain the detail of the allegations to the controlled person so that he could anticipate what the material in support might be; what steps had been taken to summarise the closed material in support without revealing names, dates or places; the nature and content of the material withheld; how effectively the special advocate had been able to challenge it on behalf of the controlled person; and what difference its disclosure might have made. All of these factors would be relevant to whether the controlled person had been "given a meaningful opportunity to contest the factual basis" for the order.

Accordingly, the provision of the Prevention of Terrorism Act 2005 (UK) for the non-disclosure of classified information, was "read down", by including the qualification "except where to do so would be incompatible with the right of the controlled person to a fair trial". ${ }^{145}$

The importance of "the facts" has been aptly illustrated in two recent decisions involving Abu Qatada, a refugee residing in the United Kingdom, alleged to be heavily involved in terrorist activities associated with al'Qaeda. ${ }^{146}$

In $R B v$ Secretary of State for the Home Department, the House of Lords dismissed Abu Qatada's (and others') challenge to the special advocate procedure used in determining their liability for deportation. ${ }^{147}$ While their Lordships acknowledged that an affected person's "ability to defend

141 Roberts $v$ Parole Board, above n 77, para 68 Lord Woolf.

$142 R v H$, above $\mathrm{n} 96$, para 22 Lord Bingham for the Court.

143 MB, above n 86, per Baroness Hale of Richmond, Lord Carswell and Lord Brown of Eaton-underHeywood. Lord Bingham applied different reasoning to the question of compliance, however he agreed that "each case would require consideration on its own facts" at para 34.

144 Ibid, para 65 Baroness Hale. See also para 85 Lord Carswell.

145 Ibid, para 72 Baroness Hale.

146 A v United Kingdom (19 February 2009) ECHR 3455/05, para 56 Judgment of the Court.

$147 R B v$ Secretary of State for the Home Department [2009] UKHL 10. 
him will be seriously impaired, if not totally destroyed, if he is not told the case against him, and his special advocate may well be in no position to rebut the case against him without obtaining the suspect's response to the closed material"; 148 in that case, the classified evidence in issue related to "safety on return", and an affected person: ${ }^{149}$

will normally be aware of those facts and indeed he will be relying on them to establish the risk that he faces on his return. His situation is not that of an individual who is unaware of the case that is made against him.

Accordingly, Lord Phillips concluded that, "when the relevant factors are weighed in the balance they do not persuade me that the use of closed material in relation to the issue of safety on return will necessarily render the process unfair". ${ }^{150}$ And, more generally, "no requirement has been demonstrated to read down [the provision for non-disclosure] in order to accommodate situations where the use of closed material in relation to safety on return will conflict with the procedural requirements of the Convention". 151

The following day Abu Qatada's (and others') challenge to the special advocate procedure for security risk certification (and resulting detention) was partially successful in the European Court of Human Rights in Av United Kingdom. ${ }^{152}$ Having accepted that "there may be restrictions on the right to a fully adversarial procedure where strictly necessary in the light of a strong countervailing public interest", the Court emphasised that "there will not be a fair trial, however, unless any difficulties caused to the defendant by a limitation on his rights are sufficiently counterbalanced by the procedures followed by the judicial authorities." ${ }^{153}$ In a similar vein to $M B$, the Court held that: ${ }^{154}$

...the special advocate could perform an important role in counterbalancing the lack of full disclosure and the lack of a full, open, adversarial hearing by testing the evidence and putting arguments on behalf of the detainee during the closed hearings. However, the special advocate could not perform this function in any useful way unless the detainee was provided with sufficient information about the allegations against him to enable him to give effective instructions to the special advocate.

\footnotetext{
148 Ibid, para 94 Lord Phillips.

149 Ibid, para 95 Lord Phillips.

150 Ibid, para 100 Lord Phillips.

151 Ibid, para 105 Lord Phillips.

152 A v United Kingdom, above n 146.

153 Ibid, para 205 Judgment of the Court.

154 Ibid, para 220 Judgment of the Court.
} 
Deciding this issue on the facts of this case, the Court held that: ${ }^{155}$

...the open material against the sixth, seventh, eighth [Mr Qatada], ninth and eleventh applicants included detailed allegations about, for example, the purchase of specific telecommunications equipment, possession of specific documents linked to named terrorist suspects and meetings with named terrorist suspects with specific dates and places. It considers that these allegations were sufficiently detailed to permit the applicants effectively to challenge them.

In contrast: 156

The principal allegations against the first and tenth applicants were that they had been involved in fundraising for terrorist groups linked to al'Qaeda. ... However, in each case the evidence which allegedly provided the link between the money raised and terrorism was not disclosed to either applicant. In these circumstances, the Court does not consider that these applicants were in a position effectively to challenge the allegations against them.

And: 157

The open allegations in respect of the third and fifth applicants were of a general nature, principally that they were members of named extremist Islamist groups linked to al'Qaeda. SIAC observed in its judgments dismissing each of these applicants' appeals that the open evidence was insubstantial and that the evidence on which it relied against them was largely to be found in the closed material. Again, the Court does not consider that these applicants were in a position effectively to challenge the allegations against them.

Thus a consistent rule of non-disclosure and the use of special advocates removes the ability of the decision-maker to balance the public interest in disclosure and the public interest in nondisclosure, and to determine whether or not a special advocate can effectively challenge the government's case. Chahal, Charkaoui, $M B$ and $A v$ United Kingdom all make it clear that, even where national security interests are in play, an affected person must still be afforded "a substantial measure or degree of procedural justice". 158

While it is accepted that, in the immigration context, the requirements of due process protection will be lower than in criminal or severe deprivation of liberty cases, there remains situations where the gravity of the potential consequences for an affected person will require high standards of procedural fairness. The Bill provides for the use of classified information in warrant of

\footnotetext{
155 Ibid, para 222 Judgment of the Court.

156 Ibid, para 223 Judgment of the Court.

157 Ibid, para 224 Judgment of the Court.

158 Chahal, above n 14, para 131 Judgment for the Court; Charkaoui, above n 18, para 27; MB, above n 86, para 32 Lord Bingham, para 76 Baroness Hale, para 85 Lord Carswell and para 90 Lord Brown.
} 
commitment proceedings, for prolonged detention, the deportation of residents who may have lived in New Zealand for a significant amount of time and built a life here, and of course in determining risk to national security, which would allow a refugee to be returned to a country despite an acknowledged risk of persecution. In such cases the potential consequences for an affected person are serious.

In light of the Bill's substantial extension of the use of classified information in immigration decision-making, it seems that special advocates have been included to justify a reduction in procedural protection, rather than to mitigate a disadvantage to which an affected person would otherwise be subject. And, even where non-disclosure is necessary, the special advocate procedure cannot invariably be guaranteed to safeguard an affected person against significant injustice. ${ }^{159}$

Accordingly, the author concludes that the special advocate procedure is insufficient protection for an affected person's right to be heard, in light of the potentially serious interests at stake. The question remains, however, whether this breach is justified under section 5 of the Bill of Rights Act 1990.

\section{Justified?}

Tipping $\mathrm{J}$ in Hansen describes a section 5 analysis as "essentially an inquiry into whether a justified end is achieved by proportionate means." 160 More specifically, the purpose for which the right is limited must be sufficiently important and the limiting measure rationally connected with that purpose. ${ }^{161}$ Further, the measure must not impair the right more than is reasonably necessary to achieve that purpose and there must be proportionality between the effects of the limiting measure and its objective. ${ }^{162}$

Tipping $\mathrm{J}$ also emphasises, however, that section 5 "is just as much an instruction to Parliament as it is to the Courts", ${ }^{163}$ and accordingly: ${ }^{164}$

the Court's function is not immutably to substitute its own view for that of the legislature. ... If the Court

does not agree [with the legislature], it must nevertheless ask itself whether the legislature was entitled

... to come to the conclusion under challenge. It is only if it was not so entitled that the Court should

find the limit to be unjustified.

$159 M B$, above n 86, para 90 Lord Brown.

$160 R v$ Hansen [2007] 3 NZLR 1, para 123 (SC) Tipping J.

161 Ibid, para 104 Tipping J.

162 Ibid, paras 104 and 123 Tipping J.

163 Ibid, para 106 Tipping J.

164 Ibid, para 123 Tipping J. 


\section{Importance of the objective and rational connection}

Non-disclosure of classified information, and the use of special advocates, is intended to protect national security and public safety. In particular, the Bill seeks to enable the deportation of potentially dangerous or undesirable individuals, without jeopardising intelligence sources or methods.

The Supreme Court of Canada in Charkaoui recognised that "one of the most fundamental responsibilities of a government is to ensure the security of its citizens." 165 Consequently, the protection of Canada's national security and related intelligence sources justified departure from fair hearing standards. ${ }^{166}$

Like Canada, and perhaps more so, New Zealand "is a net importer of security information." 167 This information is essential to national security and disclosure may adversely affect its flow and quality. Lord Carlile, independent reviewer of United Kingdom anti-terrorism legislation, argues: ${ }^{168}$

...national security could be at risk if certain types of evidence were revealed to the detainees. At risk too would be some individuals' lives. The kind of evidence I have in mind includes that provided by ... "informants", disclosure of locations used for observation, details of technical facilities available for listening to and/or reading communications, descriptions and identities of police officers and others.

Similar concerns were discussed by Lord Bingham in $R v H:{ }^{169}$

the effective investigation and prosecution of serious crime, ... may involve resort to informers and undercover agents, or the use of scientific or operational techniques (such as surveillance) which cannot be disclosed without exposing individuals to the risk of personal injury or jeopardising the success of future operations.

Disclosure also has potential risks for intelligence-sharing arrangements, as was dramatically highlighted in the case of Mohamed $v$ Secretary of State for Foreign and Commonwealth Affairs. ${ }^{170}$ Here the English High Court faced a claim of public interest immunity in respect of "seven very short paragraphs" summarising classified evidence "highly material" to allegations of torture, intended to be included in the Court's open judgment on related proceedings. ${ }^{171}$ The basis for

165 Charkaoui, above n 18, para 1 McLachlin CJ for the Court.

166 Ibid, para 68 McLachlin CJ for the Court.

167 Ibid.

168 In Forcese and Waldham, above n 48, 43-44.

$169 R v H$, above $\mathrm{n} 96$, para 18 Lord Bingham for the Court.

170 Mohamed $v$ Secretary of State for Foreign and Commonwealth Affairs [2009] EWHC 152 (Admin) Thomas LJ for the Court.

171 Ibid, para 14 Thomas LJ for the Court. 
immunity was an alleged threat by the United States that, if the information was made public, it would "re-evaluate" its intelligence sharing relationship with the United Kingdom. ${ }^{172}$

The High Court expressed its disbelief that: ${ }^{173}$

....a democratically elected and accountable government could possibly have any rational objection to placing into the public domain such a summary of what its own officials reported as to how a detainee was treated by them and which made no disclosure of sensitive intelligence matters. Indeed we did not consider that a democracy governed by the rule of law would expect a court in another democracy to suppress a summary of the evidence contained in reports by its own officials or officials of another State where the evidence was relevant to allegations of torture and cruel, inhuman or degrading treatment, politically embarrassing though it might be.

However, the Court was faced with "powerful evidence" from the Foreign Secretary that "intelligence is shared on the basis of a reciprocal understanding that the confidence in and control over it will always be retained by the State that provides it", ${ }^{174}$ and that, without this understanding, "intelligence from the United States and other foreign governments so important to national security might not be provided." 175 The Court also accepted that, "the consequences of a reconsideration of and a potential reduction in the information supplied by the United States under the shared intelligence relationship at this time would be grave indeed." 176

Thus, despite its outrage at the United States' position, the High Court held that, on balance, "it would not ...be in the public interest to expose the United Kingdom to what the Foreign Secretary still considers to be the real risk of the loss of intelligence so vital to the safety of our day to day life." 177

It is clear then, that national security concerns for the protection of security intelligence operations and important intelligence-sharing arrangements are "pressing and substantial in a free and democratic society", ${ }^{178}$ and therefore of sufficient importance to warrant limitation on the right to be heard.

172 Ibid, para 62 Thomas LJ for the Court. The Foreign Secretary later cast doubt on whether such a threat was actually made, but the judgment has not been reopened.

173 Ibid, para 69 Thomas LJ for the Court.

174 Ibid, para 74 Thomas LJ for the Court.

175 Ibid.

176 Ibid.

177 Ibid, para 107 Thomas LJ for the Court.

$178 R v$ Hansen, above n 160, para 203 McGrath J; $R$ v Oakes [1986] 1 SCR 103, para 69 Dickson CJ, Chouinard, Lamer, Wilson and Le Dain JJ. 
However, not all classified information capable of being used in immigration decision-making under the Bill compromises security or serious criminal intelligence operations and sources, or compromises these operations and sources to the same extent. To constitute a justifiable limitation, a limiting measure must be carefully designed to meet the objective in question. ${ }^{179}$

As discussed previously, classified information is no longer restricted to classified security information, instead covering a wide range of information types and sources. The argument of protection of intelligence sources and methods does not seem to carry the same weight when it is applied to all of the 14 relevant agencies under clause 4(1).

Nor is the use of classified information provided for in clause 30 restricted to concerns for "national security". Security is given a wide definition, including "the protection of New Zealand from activities in or relating to New Zealand that affect adversely New Zealand's international wellbeing, reputation...". ${ }^{180}$ While security, in the current international climate, requires broad categorisation, activities carrying reputational risk do not warrant the same treatment as espionage, sabotage, organised crime and terrorism.

Further, as participation in transnational crime and terrorist activities are both easily covered by the definition of security itself, the inclusion of criminal conduct in clause 30(1) may cover entirely domestic, and is not limited to serious or substantiated, offending.

The connection of minor, and mere allegations of, domestic criminal offending to the national security and public safety objectives of non-disclosure is tenuous, and raises considerable issues as to minimal impairment and the overall question of proportionality, discussed below.

\section{Minimal impairment}

While impairment of the right "as little as possible" was not intended to be an absolute, literal, requirement, any limitation must be no more than is reasonably necessary to achieve its purpose. ${ }^{181}$ Therefore, if Parliament might have sufficiently achieved its national security and public safety objectives by another method involving less cost to the right to be heard, the proposed limitation on disclosure will not be justified. ${ }^{182}$

The Bill's provision for non-disclosure of classified information and the use of special advocates could be substantially improved and, accordingly, the disadvantage to an affected person significantly reduced, without cost to the national security and public safety objectives of nondisclosure.

$179 R v$ Hansen, above n 160, para 204 McGrath J.

180 Immigration Bill 2007, no 132-2, cl 4(1).

$181 R v$ Hansen, above $\mathrm{n} 160$, para 79 Blanchard J.

182 Ibid, para 126 Tipping J. 


\section{For example:}

\section{(a) Communication}

The almost complete restriction on communication once the special advocate has become privy to the classified information is perhaps the most fundamental criticism of the special advocate function.

The communication rules reflect the government's concern for inadvertent disclosure: information conveyed to the named person through the questions asked. The Select Committee explains: "we are told that this clause is necessary to prevent classified information being inadvertently released." 183

Parliamentary committees in the United Kingdom have strongly argued in favour of a relaxation of the restriction on communication. ${ }^{184}$ The Joint Committee on Human Rights states: "in our view it is essential, if Special Advocates are to be able to perform their function, that there is greater opportunity than currently exists for communication between the Special Advocate and the controlled person." 185 The Committee raised the suggestion that inadvertent disclosure could be prevented by the presence of someone from the Special Advocates Support Office (SASO) recording any meetings and it admitted that some topics would be more capable than others of being discussed. ${ }^{186}$ This proposition has support from the Canadian Senate Special Committee: "he or she might communicate with the client in the company of another person, likewise sworn to secrecy, so that there can be close monitoring of what is discussed and inadvertent errors of disclosure prevented." 187

A similar communication procedure is already utilised by the Canadian Security and Intelligence Review Committee (SIRC) although, notably, was not adopted by the Canadian legislature following Charkaoui. SIRC is a body of individuals appointed by the Governor-inCouncil to review the Canadian SIS. ${ }^{188}$ Prior to 2002, if the government sought to remove a permanent resident on national security grounds, a report on the grounds for inadmissibility of that affected person would be issued to SIRC to investigate the report's accuracy. ${ }^{189}$ SIRC members

183 See Immigration Bill 2007, no 132-2 (Select Committee report) 11.

184 House of Commons Constitutional Affairs Committee, above n 72, para 86; Joint Committee on Human Rights, above n 48, paras 40 and 41.

185 Joint Committee on Human Rights, above n 1, para 205.

186 Ibid, para 203.

187 Special Senate Committee on the Anti-Terrorism Act Fundamental Justice in Extraordinary Times: Main Report of the Special Senate Committee on the Anti-Terrorism Act (Ottawa, 2007) 36.

188 Canadian Security Intelligence Service Act RSC 1985 c C-23, s 38.

189 Forcese and Waldham, above n 48, 6. 
were provided with all the information relied upon and broad powers to subpoena persons and documents. ${ }^{190}$ Importantly, SIRC counsel were able to maintain contact with the affected person and his or her counsel throughout the process, subject only to an obligation to prevent prejudicial disclosure. ${ }^{191}$ According to Forcese and Waldham: ${ }^{192}$

this questioning, done in an oblique manner to avoid involuntary disclosures of secret information, is central in unearthing potentially exculpatory information ... We were told that neither SIRC inhouse or outside counsel have ever received any complaints from the government that this contact with the named person has resulted in an involuntary disclosure injurious to national security.

Forcese and Waldham argue that there is simply no reason to presume that special advocates are more prone to involuntary disclosure than government lawyers or security service interviewers, and that the skills obtained in years of work as a barrister adequately equip the special advocate to steer around such disclosure. ${ }^{193}$

It is difficult to draw a conclusion on this issue with only a limited knowledge of the nature of the information and the risk of inadvertent disclosure. However it does seem that the communication restriction requires further consideration and the claim that it is necessary be thoroughly tested.

(b) Information

As discussed previously, the disadvantage to the affected person of non-disclosure is further compounded by the risk that the decision maker or reviewer will not have all the information before them. This risk could be reduced by increasing the resources and investigative powers of the special advocates.

In the United Kingdom special advocates are supported by the SASO, a branch of the Treasury Solicitor's Department. SASO includes lawyers split between an "open" team and a "closed" team. ${ }^{194}$ The latter have access to the classified material while the former deal with affected persons and their legal advisors. Special advocates with experience under the SASO system and the less formal and under-resourced system prior to SASO claim this is a significant improvement. ${ }^{195}$

In contrast, the Bill does not detail the role the "designated agency" will fulfil in relation to the special advocate, other than those points previously mentioned. Without full resourcing, the

190 Ibid.

191 Ibid, 6-7.

192 Ibid, 9.

193 Ibid, 64

194 Treasury Solicitors Department, above n 15, para 86.

195 Forcese and Waldham, above n 48, 31. 
inequality of arms between the government and the special advocate will render the latter simply token.

Further, while the Bill provides for communication with persons for administrative purposes, this communication can not be connected to the substance of the proceedings. ${ }^{196}$ This not only restricts the availability of substantive support, it also precludes special advocates from obtaining expert, and other, evidence.

The lack of investigative or forensic tools available to the special advocates is a serious limitation. In order to effectively challenge the substantive claims against the affected person, a special advocate needs the ability to seek and obtain other governmental records believed to be relevant, and obtain expert evidence, in order to detect gaps, inconsistencies and weaknesses in the government's case. ${ }^{197}$

In the United Kingdom, the Special Immigration Appeals Commission (Procedure) Rules require the Secretary of State to "make a reasonable search for exculpatory material", and must file any material discovered with the Commission. ${ }^{198}$ This exculpatory material must then be served on the affected person, unless this would not be in the public interest, in which case it is served on the special advocate. ${ }^{199}$

An enforceable duty on the part of the Crown to provide the special advocate with all relevant classified information, or at least all relevant exculpatory material, would strengthen the position of the Tribunal or court to determine an affected person's case in full light of the relevant facts. ${ }^{200}$ While "protective anxiety" may still work against full disclosure, there would at least be a means through which the special advocate could request further government records and a positive obligation on the Crown enforceable by the Tribunal or court. "Relevance" could be determined by the Tribunal or court, applying a standard which reflects the potential interests at stake and the Bill's policy of expeditious determination of proceedings. ${ }^{201}$

\section{(c) Independence}

It is also unclear whether the "designated agency" will be a new agency established for this purpose or added to an existing agency, raising potential issues as to the independence of the special

196 Immigration Bill, no 132-2, cl 238(4).

197 House of Commons Constitutional Affairs Committee, above n 72, paras 75-81; Forcese and Waldham, above n 48, 27.

198 Special Immigration Appeals Commission (Procedure) Rules 2003 (UK), R 10A(2)(a).

199 Ibid, R 10A(8).

200 House of Commons Constitutional Affairs Committee, above n 72, para 96.

201 Immigration Bill 2007, no 132-2, cl 198(1). 
advocate function. It is essential that affected persons see the special advocate to be acting on their behalf, and not as an extension of the state.

In the United Kingdom the administrative and physical proximity of SASO to the government has raised concerns among civil society groups, affected persons and their counsel about its independence. 202

The risk of affiliation is increased by the Bill's requirement that the chief executive of the Department administering the Act pay the costs of the special advocate. ${ }^{203}$ The designated agency itself should pay the special advocates, to ensure there is no actual or apparent conflict of interest on behalf of the Department. As noted by the Inspector-General, funding special advocates is "an expensive part of the process". ${ }^{204}$ It is important that the level of funding is high enough to ensure that competent, experienced counsel are recruited and retained as special advocates. The proposed extension of the use of classified information is certain to result in an increase in the function's use in the future.

(d) Alternatives

The above limitations on the special advocate function are problematic because the Bill does not provide for protection against prejudicial disclosure by measures less than non-disclosure and the use of special advocates.

As discussed, the Bill significantly extends the definition and range of use of classified information, such that the potential seriousness of any risk of prejudice from disclosure of that information varies significantly. However, despite this substantial variation, all classified information is treated the same; it cannot be disclosed to an affected person.

There is a compelling argument that the Tribunal or court should be able to balance the public interest in disclosure against the public interest in non-disclosure, such as was carried out by the English High Court in $R$ (Mohamed) $v$ Secretary of State. ${ }^{205}$

Where the public interest in disclosure is greater, the Tribunal or court could be empowered to authorise forms and conditions of disclosure that reflect this balancing. For example, where disclosure of information poses a reputational risk, in camera proceedings attended by an affected person, accompanied by a non-disclosure undertaking and/or a publication ban, may be more appropriate than non-disclosure and the exclusion of the affected person. ${ }^{206}$

\footnotetext{
202 Forcese and Waldham, above n 48, 30.

203 Immigration Bill 2007, no 132-2, cl 235.

204 Hon Paul Neazor "New Zealand Security Intelligence Service: Annual Report" (30 June 2008).

205 Mohamed v Secretary of State for Foreign and Commonwealth Affairs, above n 170.

206 Forcese and Waldham, above n 48, 47.
} 
On the other hand, in circumstances where genuine national security or public safety interests are at stake, including where security intelligence operations could be jeopardised, the Tribunal or court would be open to decide that the special advocate function was the only form of disclosure available. The balancing exercise, however, would ensure that there is a solid evidential basis for those security or safety concerns.

This balance would increase fairness to the affected person by ensuring that non-disclosure is necessary and justified in all the circumstances, while still achieving Parliament's objective of enabling the deportation of potentially dangerous or undesirable individuals, without jeopardising intelligence sources or methods.

\section{Overall proportionality}

The final question is whether the harm to affected persons is proportionate to the social advantage from non-disclosure; "the more severe the deleterious effects of a measure, the more important the objective must be." 207

This issue underlies many of the points already made; non-disclosure and the special advocate function, as currently proposed, constitutes a substantial derogation from the right to be heard, with potentially very serious consequences for an affected person. At the same time, national security and public safety are perhaps the most fundamental concerns of any government, and fall into an area in which the courts are more hesitant to interfere. Tipping J in Hansen explains: 208

There is a spectrum which extends from matters which involve major political, social or economic decisions at one end to matters which have a substantial legal content at the other. The closer to the legal end of the spectrum, the greater the intensity of the Court's review is likely to be. The reality is, however, that a particular matter may partake of a number of different elements involving different aspects of this spectrum.

The last statement is especially pertinent, as while national security is very much at the political end of the spectrum, an area in which the court is well qualified to make its own judgment is the requirements of a fair hearing.

Had the non-disclosure of classified information been limited to security intelligence information that was genuinely sensitive due to the nature and sources of that information, the argument for institutional deference would be more persuasive.

However, as previously discussed, the use of classified information under the Bill goes much further, encompassing information from 14 different government agencies, and able to be classified

$207 R v$ Hansen, above n 160, para 103 Tipping J; $R$ v Oakes, above n 178, para 71 Dickson CJ, Chouinard, Lamer, Wilson and Le Dain JJ.

$208 R$ v Hansen, above n 160, para 116 Tipping J. 
simply on the basis that it, might, disclose operational methods and relates to allegations of minor criminal offending or activities that could potentially embarrass the New Zealand government.

While these concerns are not necessarily trivial, they do not justify the automatic non-disclosure of information to an affected person facing deportation, with its potentially serious consequences. The introduction of special advocates cannot be used to justify a reduction in the procedural protection that an affected person would otherwise be entitled to.

Therefore without the ability of the Tribunal or courts to ensure that non-disclosure is necessary, the author concludes that the non-disclosure of classified information under the Bill, with the use of special advocates, is not a justifiable limitation on the right to be heard.

\section{CONCLUSION}

A special advocate in the United Kingdom described their role: ${ }^{209}$

I see it as mitigating the unfairness which is inherent in a system where the appellant, one party to the proceedings, does not know all the material that they are supposed to be meeting or answering. ... The system of Special Advocates can never overcome that irreducible element of unfairness but, having accepted that, I think that the functions that we try to perform can at least mitigate it and is better than not having a system where there is a partisan representative.

The special advocate function established by the Bill retains this intrinsic problem. Nonetheless, the author has suggested a number of improvements with which the function could at least be a justifiable breach of the Bill of Rights Act.

First, not all the interests protected by non-disclosure under the Bill warrant this response in light of the interests at stake for an affected person. The Tribunal or court should have the ability, in proceedings before it, to balance public interest in disclosure against the public interest in nondisclosure. Where the public interest in disclosure is greater, the Tribunal or court should be empowered to authorise forms and conditions of disclosure that reflect this balancing.

Second, where non-disclosure is necessary, the special advocate must be given sufficient ability to present the affected person's case. This requires full disclosure by the Minister of all relevant classified information, enforceable by the Tribunal or court. The proposed communication regime should also be reconsidered and the special advocate must be guaranteed necessary support and funding, whilst maintaining sufficient independence from the state.

As a general conclusion the author again emphasises that special advocates can only serve to mitigate the disadvantage to which the affected person would otherwise be subject. For this reason we should be very wary of "function creep". True procedural fairness hinges on a person's right to

209 Andy Nichol QC in Joint Committee on Human Rights, above n 1, para 211. 
know the case and to meet it, a right that the proposed special advocate system cannot supplant or satisfy. 